\title{
Creating Greener Citizens: Political Liberalism and a Robust Environmental Education. ${ }^{1}$
}

Proponents of environmentalist views often urge the teaching of such views and the inculcation of 'green' values within the educational curriculum of schools as a key component of achieving their ends. Such radical transformation of the attitudes, lifestyles, and preferences of individuals that is often said to be required to solve major environmental problems cannot be achieved without directing educational institutions to inculcate an environmentalist ethic.

It might seem that modern versions of political morality that refuse to take a stance on controversial questions - religious, ethical, philosophical - or eschew appeal to perfectionist doctrines, are beset by a particularly acute difficulty in this regard. To the extent that environmentalist views embody claims about ethical matters such as how individuals should live their lives, they fall foul of this version of political morality. For example, the most developed such account - Rawlsian political liberalism - seeks to articulate conceptions of justice and legitimacy that can gain the support of an overlapping consensus of the many reasonable comprehensive ethical, philosophical, and religious doctrines that inevitably exist within a liberal democratic society. It aims to do so, without itself taking an ethical, philosophical, or religious position, or taking a stand with regard to the truth or falsity of any such doctrine. Political liberalism follows this path so as not to prejudice the affirmation of a conception of justice by ethically, philosophically, or religiously reasonable views, but rather to generate wide and stable support. ${ }^{2}$ Whilst political liberalism mandates a minimalist role for children's education - one that prepares children for citizenship in a society of free and equal citizens with the capacity to form, revise, and pursue their own conception of the good and the ability to live by principles of justice appropriate for such a society - the fostering of these 'political virtues' does not extend to the teaching of wider ethical doctrines. Green ideals, like Muslim or Christian ideals, are too controversial to be part of the compulsory curriculum in such a society.

\footnotetext{
1 [Omitted]

${ }^{2}$ For the sake of simplicity, henceforth I use 'ethical ideal' or 'ethical doctrine' to cover ethical, philosophical, or religious views.
} 
This article evaluates the resources available to political liberalism to respond to the challenge of bringing the teaching of green values and virtues within the national curriculum. Environmental issues are becoming ever more prominent and important political issues. The alleged incompatibility of environmental education and considerations of basic justice strikes many as a serious flaw in any view of political morality; one that detracts from its plausibility. Rather than rejecting political liberalism in favour of an environmentalist or ecological framework, I will seek a reconciliation of the two. ${ }^{3}$ The extension of existing, and well worked out conceptions of justice, to other areas of political concern bestows credence in both directions: political liberalism looks even more plausible and robust because it covers more cases of moral concern, and environmentalism cements its claim to be a critical question capable of being dealt with as part of the most highly respected and plausible view of justice.

More specifically, I will argue that environmental concerns differ in morally important ways from other ethical, philosophical, and religious views that are typically off-limits to political liberalism. Much that passes as green ideals are not simply a conception of the good life in the manner that religious views, for example, are. Rather, many environmental goods are crucial to the realisation of socioeconomic justice and therefore escape the requirement of state neutrality on endorsing the truth or importance of their role. A minimal political liberal education includes teaching about justice-based concerns as part of a compulsory national curriculum.

This paper has the following format. Section I outlines the apparent conflict between environmentalism and the model of education mandated by political liberalism. As well as viewing the broad contours of political liberalism, I consider (and reject) three possible responses to this conflict, including Bell's recent (2004) innovative attempt to reconcile political liberal education and environmental virtues. Section II draws and elaborates a crucial distinction between issues of the good and issues of socioeconomic justice. Political liberalism requires neutrality only between matters of the former kind. Many environmental goods (and the values that attach to them) that are ordinarily thought to be comprehensive ideals are, I argue, part of the requirements of basic socioeconomic justice. Political liberalism need not be neutral in educational terms on such matters. Section III expands upon environmental goods as socioeconomic goods by illustrating how they are crucial to realising justice, and fleshes out how

\footnotetext{
${ }^{3}$ Rejection of political liberalism (or any other liberal view) is, of course, a serious option, but not one that I consider here (for this see e.g., Nussbaum 2006). Nor, it should be noted, do I offer any detailed or concerted defence of political liberalism per se. Rather, I take political liberalism largely as correct, and (after laying out its rough contours) see where this leads us, by extension, in terms of environmentalist concerns.
} 
this could be incorporated as part of a compulsory political liberal national curriculum. It also considers what would be left out (in terms of the concerns of environmentalists) and how significant this might be. Section IV concludes.

\section{I}

Rawlsian political liberalism takes as its starting point the 'fact of reasonable pluralism' (Rawls 1996, pp.63-66). A diversity of ethical, philosophical, religious and other 'comprehensive' doctrines is an inevitable and permanent outcome of democracy where the basic rights and liberties of free institutions obtain; pluralism is the result of the exercise of practical reason within the framework of free institutions (Rawls 1996, pp.36-37).

Reasonable pluralism refers, that is, to a multitude of different, yet reasonable, religious doctrines. In Rawls's conception reasonableness is characterised by two moral virtues. First, reasonable people are 'ready to propose fair terms of cooperation and to abide by them provided others do', and to achieve a system of social cooperation guided by principles of justice that are acceptable to every reasonable person (Rawls 1996, pp.54). Second, it involves 'the willingness to recognise the burdens of judgment and to accept their consequences for the use of public reason in directing the legitimate exercise of political power in a constitutional regime.' (Rawls 1996, p.54). This is a notion that characterises the nature of people's beliefs. In this sense, one's view is reasonable if one possesses the requisite power of theoretical and practical reason, and one's beliefs are the product of one's employment of these powers under conditions of freedom. These powers consist in the ability to weigh evidence appropriately, draw inferences, balance competing considerations, and so on. Rawls argues that humans are beset by various 'burdens of judgment' such that the exercise of our theoretical, practical, and moral faculties under conditions of freedom inevitably gives rise to a plurality of comprehensive doctrines. Moreover, because this pluralism is a product of the free activity of persons, even those who are adept at deliberating about ethical, religious, and philosophical matters, we should regard it as a permanent feature of free democratic societies, rather than a product of ignorance or prejudice that may disappear or be overcome.

Rawls's conception of legitimacy purports to identify the conditions under which legal and political institutions have de jure authority understood as the (Hohfeldian) power to direct citizens' lives through binding laws and the right to enforce the law through the penal system. A well-known aspect of Rawls's view is that political institutions have legitimate authority if they 
are guided by a constitution that is responsive to ideas and principles acceptable to 'free and equal' citizens who are stipulated as being reasonable. In other words, the justification of political power must be conducted in terms that do not gainsay the assumptions, ideals, or conclusions of any wide variety of ethical or religious conceptions that are held by reasonable citizens. We must, Rawls insists, elaborate 'political' conceptions of social cooperation that draw on the democratic ideals of freedom and equality, but which stand free of ethical, philosophical, or religious claims ('comprehensive' claims) that are disputed by reasonable citizens. The aim is to create an 'overlapping consensus' of reasonable comprehensive doctrines that support this conception of justice. This distinctly 'political' liberalism is to be distinguished from the 'comprehensive' liberalisms of Mill, or Kant, which provide synoptic world-views aimed at dealing with an array of issues, including (but not limited to) the correct principles of justice, but which remain controversial because they depend upon conceptions of the good that are not widely shared in democratic societies, such as Mill's account that rests on individuality, or Kant's account of moral autonomy.

Within this political liberal framework, the education of children plays an important, though strictly limited function. According to Rawls (in a discussion that occurs in the context of religious groups), this education will include:

such things as knowledge of their constitutional and civic rights so that, for example, they know that liberty of conscience exists in their society and that apostasy is not a legal crime, all this is to ensure that their continued membership when they come of age is not based simply on ignorance of their basic rights or fear of punishment for offenses that do not exist. Moreover, their education should also prepare them to be fully cooperating members of a society and enable them to be self-supporting; it should also encourage the political virtues so that they want to honor the fair terms of social cooperation in their relations with the rest of society (Rawls 1996, p.199. See also Rawls 2001, p.156).

As Rawls elaborates in a later restatement, this education should promote respect for each other as equals as part of a capacity for a 'sense of justice', as well as inculcating the virtues of reasonableness, a sense of fairness, and a spirit of compromise (Rawls 2001, p.116. See also Bell 2004, p.39). What, exactly, these things might unpack to mean is the focus of the last section of this piece. Nevertheless, we should note that these are necessary components of a political liberal 
educational curriculum. Whilst these aspects are compulsory, it does not follow that these are the only things that can be taught. Beyond these aspects, political liberalism leaves room for families, communities, and schools to determine the content of how their children are educated. This is likely to vary significantly across schools, as we see with schools that promote particular religious faiths, or philosophical positions, or even an environmentalist ethic.

Whilst there is, perhaps, space for the inclusion of environmental concerns in the classroom, this is likely to jar considerably with defenders of environmentalism who view mechanisms for changing attitudes, preferences, and behaviours as necessary for resolving serious ecological problems (with potentially catastrophic consequences) not as a voluntarily adopted educational ethi for some schools - as Catholicism or Islam might be adopted as a wider educational aim but as a core mandatory component of education for every school child.

On the face of things, political liberalism and environmentalism are radically incompatible (see Dobson 2001, p.vii for examples). The latter is ordinarily conceived of as a world view, a conception of the good; the very thing that political liberalism eschews appeal to, and attempts to steer a neutral path between. Although it comes in many forms, at its core, environmentalism is committed to the improvement of the health of the environment and its repair and conservation. In particular, this includes concerns of nonhuman entities and elements, and the proper relationship or balance between human life and the various natural systems upon which it depends. Typically, defences of these 'green' values go beyond the minimalism of political liberalism and constitute a more 'comprehensive' or perfectionist political doctrine - one that affirms a certain picture of what the good life consists of. Views vary, of course, but the trajectory away from political liberalism's eschewing of such commitments is, prima facie, clear.

This has implications for education, and these implications are not modest. The thoroughgoing reform of values such aims would require would necessitate educational mechanisms for attempting to create green citizens with the knowledge and skills to protect the environment, or save the Earth, from the deleterious effects of the kinds of processes liberalism is often thought to engender. This would include such things as the capacities to make environmentally aware decisions, the capacity to understand scientific evidence, and to bring political, economic, and deliberative resources to bear on specific issues. It would require a less individualistic or atomistic ethos than is ordinarily considered to be a mainstay of liberal conceptions of political morality. As the UNESCO report from the 1977 Intergovernmental Conference on 
Environmental Education - which Bell cites in his recent consideration of this question - states, environmental education must be both universal, comprehensive, and holistic (UNESCO 1979, pp.12-14). That is, it must apply to all children and all school curricula everywhere; it must cover the full range of environmental issues that threaten the planet and life on it; and it must draw in many educational disciplines, from sciences to social sciences, arts, and humanities. The aim is not simply to transmit the right attitudes, but to develop the capacity of children to actively think in a pro-environmentalist manner for themselves; to give them exposure to issues, and the necessary critical tools and experiential resources to work through the issues in a sophisticated manner, as well as to extrapolate to new issues as they arise. If the public are to be guardians of the environment, then they will require the proper educational background to later enact the policies necessary to save the planet. As Bell writes:

If the aim is to protect the environment by creating new generations of citizens, who are 'greener' than their parents and grandparents, it will not be enough to make environmental education an entitlement. It is only by making it compulsory that we can ensure that 'everyone becomes environmentally conscious through proper environmental education'. Environmental education must be 'an essential part of every pupil's curriculum' (Bell 2004, p.43, citing Palmer and Neal 1994, pp.14 and 28 respectively. Footnote omitted).

I wish to elaborate and defend the claim that political liberalism and a serious environmentalism are, contrary to first appearances, in large part compatible. Not all environmentalist concerns or educational aspirations are realisable under political liberalism, but the most central ones - more so than rival attempts at reconciliation allow - are. Several possibilities or routes to achieving this reconciliation are possible. I will give these brief consideration, and reasons that count against them, before moving to the positive argument in the next section.

One tactic, presented by (amongst others) Baxter $(2000 ; 2005 ; 2006)$, is to broaden the foundations of anti-perfectionist versions of political morality to include nonhuman entities as part of the 'community' of entities to whom justice is owed. This solution seeks to guarantee the inclusion of certain ecological aspects in any outcomes agreed to in the initial contractualist framework that stands at the root of views such as political liberalism by including parties with those interest as part of the original contract. Whilst for Rawls the contracting parties are 
humans, Baxter adds much of nonhuman nature whose interests (like those of other 'inarticulate' groups such as the severely disables) are represented by proxy.

Such a view has the ability (if correct) of building a very strong ecological position into the political liberal-type framework. In terms of education it would likely mandate considerable and radical revision of a national curriculum to include a wide range of activities and learning about the protection of entities that are considered fellow citizens in a common project.

I wish to set this position aside, for I have argued against it at length elsewhere (*** self reference deleted $\left.{ }^{* * *}\right)$. We need only note that it does not provide an answer to our current predicament because it undermines the neutrality of political liberalism. Admitting nonhuman entities into the community of justice may be possible, but it does so at the cost of creating two competing versions of political liberalism. Political liberalism was supposed to provide a neutral framework for steering between different comprehensive conceptions of the good, and an agreed set of procedures that allowed wider policy questions outside of matters of basic justice to be resolved fairly. As Baxter acknowledges, the upshot of his argument is now two versions of a neutralist framework - one with nonhuman entities included, one with only human entities included - and no agreed upon criteria for choosing which is correct (Baxter 2000, p.62). Incorporating ecological concerns in this way has simply pushed the issue back one level of philosophical abstraction. It does not solve the problem so much as deepen it.

A second response - one touched upon by Bell (2004, p.40) - is one that attempts to 'avoid' the problem by suggesting that the essential curriculum mandated by political liberalism is more expansive than it appears at first sight, and is likely to include a good deal of the environmentalist's concerns and points. Bell suggests this is inadequate because it implies the national curriculum would be almost wholly occupied with the task of creating 'good citizens' and this curriculum would be compulsory across all schools. 'Accepting this 'solution' seems to undermine the idea of political liberalism as a "module, an essential constituent part, that fits into and can be supported by various reasonable comprehensive doctrines that endure in the society regulated by [the principles of political liberalism]".' (Bell 2004, p.40, quoting Rawls 1993, p.12. Interpolation in Bell).

Bell's dismissal of this option is too quick. It does not follow that a wider understanding of the role of a political liberal education will eat up the entire national curriculum. I will take this up in 
the next section where I argue that educating about justice is part of the political liberal position on education, and many environmental concerns and ideals form part of any acceptable conception of socioeconomic justice. Before proceeding, I wish to consider one final option which is endorsed by Bell in his recent exploration of this question (2004).

Rawls's statement about education in a political liberal society includes the encouraging of the 'political virtues' so that citizens may play a fully cooperative role in their society (Rawls 1996, p.199). Bell argues that these political virtues are likely to include certain environmentalist virtues, though only a limited amount. Noting that Rawls's account requires a 'just savings principle' to meet the requirements of justice to future generations in order to realise and preserve a just society, Bell suggests that this will include a conception of 'sustainability' (Rawls 1999, p.257; Bell 2004, p.46). Admittedly, this may not be a particularly 'green' conception of sustainability or sustainable development, because Rawls's conception is not committed to anything so specific, but might well be compatible with it. Wissenberg's (1998) infamous 'global Manhattan' - rather than a world of open green spaces - may be a plausible option for satisfying the Rawlsian-based notion of sustainability for achieving a decent standard of living through social cooperation within a society that exists across generations.

What sustainability will require is, therefore, to be determined by citizens through informed discussion. Such informed discussion is predicated upon an education sufficient to allow serious contemplation and deliberation about such matters. 'In addition to promoting "political virtues", which are designed to ensure intra-generational justice, the [political liberal] curriculum should aim to promote "sustainability virtues", which are designed to ensure inter-generational justice.' (Bell 2004, p.47). And, '[i]n short, the [political liberal] curriculum should aim to promote a positive attitude toward "sustainability" and a basic understanding of the environmental and social science frameworks that citizens need to participate in "sustainability" decisions.' (Bell 2004, p.47).

Whilst this response is promising in terms of widening the understanding of political virtues to include a more environmental slant, it expands it in the wrong direction, and it leaves too much out that might otherwise be included. Relying on the just savings principle raises the controversial issue of Rawls's position on intergenerational justice, and the difficulties this conception brings. In the next section I will argue that there are more straightforward parts of Rawls's conception of intra-generational justice that do in fact cover many environmental 
concerns and virtues. Moreover, this solution leaves the vast majority of environmental issues to be settled by democratic procedures, and the wider content of the educational curriculum to be determined by the preferences of the society. If environmental concerns are to be addressed by public policy or 'green ideals' are to form part of children's education, then (beyond the sustainability virtues) this is permissible if enough citizens can be convinced of their value. In this sense, green ideals remain a conception of the good, the merits of which are to be debated and haggled over in the political process by an informed citizenry. If enough people can be convinced - as they may be convinced by the worth of other features of other conceptions of the good such as prayers in schools - then these ideals may permissibly be instituted. If not, not.

Proponents of environmental justice are likely to be dissatisfied with this conclusion. The point is that environmental issues are so fundamental to human (and other) life and flourishing, that they are matters of justice, and not simply preferences to be argued over in public debate, to be adopted or not adopted as a society sees fit. In this they differ from conceptions of the good, such as religious doctrines. Much of the environmentalist position is conceived of by its defenders as matters of justice, not of the good. It is to a defence of this position that I now turn.

\section{II}

In the face of reasonable pluralism, Rawlsian political liberalism defends an anti-perfectionist position, rather than affirming the truth or falsity of any particular view or views of the good. By contrast, however, Rawls also defends a non-neutral position with regard to socioeconomic matters of justice. ${ }^{4}$ Indeed, Rawls defends a non-neutral and rather specific set of socioeconomic resources - his 'primary social goods' - as a requirement of justice. These goods include not only rights and liberties (to freedom of speech, association, and so forth), but to opportunities (to positions of advantage), and to a specific distribution of wealth and income that arises from the differential positions of advantage and the employment of talents. Anti-perfectionism is strictly limited to certain areas (questions of the good), and is not intended to apply across the board (questions of how resources ought to be distributed). Issues of fair resource division are not something to be argued over within democratic institutions on the basis of deliberation or preferences. Rawls's second principle of justice, which is intended to shape the basic structure of society on such matters, makes this clear:

\footnotetext{
${ }^{4}$ Whether this asymmetrical treatments of justice and the good is sustainable is the subject of the next section.
} 
Social and economic inequalities are to be arranged so that they are both: (a) to the benefit of the least advantaged, [the Difference Principle] and (b) attached to offices and positions open to all under conditions of fair equality of opportunity [the Fair Equality of Opportunity Principle] (Rawls 1971, p.302).

The difference principle prioritises the position of the least advantaged in the distribution of particular resources (wealth and income) and provides a guarantee of a level of these resources that will enable individuals to make full use of their rights, liberties, and opportunities in the pursuit of their particular conception of the good (whatever that turns out to be). Something like the difference principle is, according to Rawls, a necessary component of any reasonable conception of justice.

It is these resources - primary social goods - and their governing principles of distribution Rawls's principles of justice - that provides the point of embarkation for my argument that a wide range of environmental goods and concerns can be included within the framework of basic justice, rather than treated as matters of the good. I will argue that environmental goods, that is, are more appropriately conceived in the same manner as Rawls's other primary goods, or as goods that contribute to them.

Rawls describes primary social goods as those resources that, whatever else we need in life, we need these in order to frame, revise, and pursue a conception of the good. The link between certain environmental goods and the primary goods is so obvious in cases such as breathable air that their provision is beyond question. Without breathable air the primary goods of rights, liberties, opportunities, and so forth would be pointless. Yet, many environmental goods will impact on liberties, opportunities, and other resources guaranteed by the basic principles of justice in a similar manner. Polluted rivers impact upon the value of land. Removal of woodlands, open countryside, clean water, unpolluted seas, particular species of animals and insects, can seriously curtail the liberties and opportunities of citizens. The existence of such liberties and opportunities is premised upon the existence of natural resources. Without them, citizens cannot make effective use of them. The absence of environmental goods and natural resources essential to the effective use of rights and liberties is akin to the individual who possesses the formal right to go to the opera, but who lacks the financial means to ever afford a ticket; it is a hollow right. 
The analogous case here is healthcare. An adequate level of health is necessary for our normal social functioning or protecting our opportunities. To the extent that we are unhealthy, our opportunities (or normal functioning) are impaired. Meeting health needs helps protect these opportunities. Because justice requires the protection of opportunities and liberties, then meeting healthcare needs takes on special importance. Healthcare, that is, is a special kind of good (Daniels 2008, pp.29-78). This does not mean that we should simply add healthcare to the list of primary goods. Instead, healthcare can be thought of as a necessary component for the realization of fair equality of opportunity under the second principle of justice (see Daniels 2008, pp.56-8). In a similar manner the difference principle can be seen as providing a fair distribution of certain all-purpose means for meeting the needs of food, clothing, shelter, and so forth, rather than as seeing them as primary goods themselves (Daniels 2008, p.57). The question is, instead, how extensive is the list of environmental goods that are required to give fair value to the rights that are central to social justice?

Maintaining a decent environment will be central to leading the decent lives that the goods provided as a matter of justice are intended to allow us to achieve. Securing and protecting areas of natural beauty, saving endangered species and protecting others, purifying our air and water, maintaining a delicately balanced ecosystem with all its essential parts, all of these and more are essential to this task. Because of the degree of interconnectedness of these various aspects (and our ignorance of how they fit together exactly), many will require the protection of other aspects. Purifying air and water to a sufficient level (and then maintaining it) is, upon closer inspection, an incredibly multifaceted task that extends from stemming carbon emissions, through preventing the destruction of the rain forests, to maintaining the delicate balance of flora and fauna in the oceans. This is often overlooked when simply talking of limiting pollution and purifying air as a component of basic justice. Once we begin to view environmental goods as crucial to securing justice, then many crucial parts of our ecosystem will require protection as part of this aim (Barry 2005, pp.251-60). As Bell writes: 'If providing the opportunity to experience quality environments is an effective and efficient means of maintaining and restoring the "minimum essential capacities for being [a] normal and fully cooperating [member] of society," a Rawlsian state has reason to devote resources to it.' (Bell 2004b, pp.303-4, quoting Rawls 2001, pp.171-2). Maximising the position of the worst-off will necessarily include devoting resources to other projects than just distributing income to individuals. Open green spaces, access to countryside and coastline are crucial to the mental and physical well-being of the population, and are an integral part of any policy package. What it takes to provide these things 
will include a chain of interconnected components. Similarly, a sufficient social minimum should secure a solution to food and fuel poverty that are often central environmental concerns, as well as components that regulate building and transport industries.

Similarly, current research consistently shows that the vast majority of environmental pollutants produced by industry are produced in the most socially and economically deprived areas (see Stephens et al 2001). '[W]ithout clean air many people will suffer debilitating respiratory illnesses that prevent them from engaging in "mutually beneficial social cooperation" (e.g., working) and from pursuing their conception of the good.' (Bell 2004b, pp.298-9). As we have seen, even meeting these basic requirements is an extensive task, requiring far-reaching policies and actions. The preservation of various species of animals and plants, the reduction of various activities, are all likely to be included. Attaining clean air requires not simply the reduction of emissions but the preservation of parts of the ecosystem - such as various strains of plankton and algae in the seas - that absorb $\mathrm{CO}_{2}$, and various fish and mammals for which these form vital foodstuffs and which manage the stocks of these organisms.

If I am somewhere near correct in this - that many environmental goods and concerns are rightly seen as crucial to the provision of the all-purpose means (primary goods) for pursuing a conception of the good that are guaranteed as part of an acceptable conception of justice within Rawlsian political liberalism - then this will have equally reformatory consequences for what can be taught in schools as part of a basic political liberal curriculum. As well as the abilities of critical thinking and sensitivity to balancing evidence and so forth, the political values will also include teaching and learning about how the environment impacts upon the rights, liberties, and opportunities that citizens are guaranteed within political liberal society. The link between such aspects and reciprocity and the 'fair terms of social cooperation' can also be made explicit. These aspects are, moreover, compulsory as part of the basic curriculum of teaching about justice, rather than an optional part outside of the basic political liberal national curriculum. The only question this raises is whether teaching about justice in this way is compatible with Rawls's statement about education. I consider this - along with other criticisms - in the next section.

\section{III}

I have argued that many aspects of environmental justice are more appropriately considered as matters pertaining to or impinging upon the provision of primary goods, rather than questions of the good life. As such, they are not matters that the political liberal society need remain neutral 
over. An educational curriculum within such a society must include knowledge of such features within its remit. In this, many environmental view and the goods that they endorse will be markedly different in qualitative terms than, say, religious views. The latter makes claims about the good life, whilst the former make a different type of claim: that certain goods are essential for pursuing a conception of the good, whatever that turns out to be. We might disagree over the exact nature of these goods, but these are disagreements about justice, not the good. This raises two immediate questions, or potential objections. I turn now to consider these.

The first issue concerns the nature of disagreements over the good and disagreements over socioeconomic justice. Political liberalism, as we have seen, treats these two aspects asymmetrically: it proposes anti-perfectionism in the face of different views of the good, but a non-neutral set of principles in the case of the distribution of primary goods. The objection here is that this asymmetrical stance is unsustainable. To see the power of this objection, recall that Rawls uses the notion of the burdens of judgment - which is one component (along with reciprocity) of his notion of reasonableness - to explain the existence of a plurality of comprehensive doctrines within free liberal-democratic societies, and to justify an antiperfectionist stance. Yet, if the burdens of judgment explain disagreement about the good, then it would seem likely that they also explain disagreement about distributive justice (Caney 1999; Clayton 1999). Disagreement is not somehow absent from questions of distributive justice. Indeed, certain disagreements about justice seem as easily explicable in terms of the burdens as do disagreements about the good. For instance, divergent views about the appropriate level (if any) of economic redistribution, or about the minimum wage, or about the permissibility of the death penalty, or about an appropriate level of state-funded healthcare, seem as easily explained by appeal to the criteria of the burdens as do such things as the legitimacy of abortion, Sunday Trading laws, fox hunting, or the place of the arts in a worthwhile life (Caney 1999, pp.22-23). ${ }^{5}$ This leaves me, then, with the following dilemma:

Either:

(1) We admit that reasonable disagreement applies to questions of justice and retract a partisan commitment to any principles of (re)distribution as a component part of a just framework;

\footnotetext{
5 This does not imply that all questions of justice are subject to such disagreement. There may be agreement over some issues. There is, for example, remarkable consensus over the importance of the Rule of Law. But, this does not remove the complaint that some issues of justice are the subject of widespread disagreement, that they do not differ from disagreement over questions of the good in this respect, and both fit the model of explanation offered by the burdens of judgment.
} 
Or:

(2) We deny that questions of justice are subject to reasonable disagreement and accept that this also holds for questions about the good.

Either horn of the dilemma would appear to undermine political liberalism as outlined here. Grasping the first horn would mean that the best we could hope for would be some kind of proceduralist framework for deciding issues of socioeconomic justice. This type of view is defended by neutralists such as Barry (1995), and would shrink the values and virtues to be compulsorily taught in schools to a bare minimum. The aim would simply be to establish a political framework in which people could collectively determine laws and policies - via free political debate - on all questions of the good, distributive justice, and (as part of either) environmental issues. What principles or policies would be adopted would depend upon the ability of their proponents to convince their fellow citizens of their merits.

Grasping the second horn would mean retaining a commitment to a particular set of principles of justice at the cost of being pushed towards perfectionism. That is, it might no longer be possible to rule out the applicability of the burdens to certain claims about the good. The state would have to give up its stance of neutrality in certain areas and endorse a particular conception of the good.

Such an objection, however, misunderstands the true nature of political liberalism, because it fails to grasp the role that reasonableness plays in the construction of the political liberal view. The reason it is possible to escape the proposed dilemma and maintain the asymmetrical position with regard to justice and the good that the position defended herein depends upon is because it is only reasonable views to which the political liberal framework must be acceptable, and not to all views. This is a crucial, yet oft-neglected distinction. As we saw at the outset, a necessary condition of the acceptability of a conception of justice is that it fulfills the reciprocity requirement (as one of the two component parts of reasonableness). Reasonable citizens are reciprocal in that they are 'ready to propose fair terms of social cooperation and to abide by them provided other do' (Rawls 1993, p.54). In distributive terms, this means that we must treat the goods produced by social cooperation as the legitimate subject of distributive principles (Rawls 1996, p.lviii). This is required by Rawls's earlier claim that all citizens require certain allpurpose means to make use of the rights, liberties and opportunities afforded them by his first principle of justice (Rawls 1996, p.xlviii). Without such resources, these liberties and 
opportunities are empty, for the realization of their full worth is tied to the level of resources that the individuals holding them have. Rawls lists a few concrete items that, as a minimum, this would require: the public financing of elections, equality of opportunity, a decent distribution of income, society to act as the employer of last resort, and basic healthcare for all citizens (Rawls 1996, pp.lviii-lix). To this, I have argued, we should add a swathe of environmental goods that are prerequisites for many of the items Rawls lists.

The reciprocity requirement means that views such as Nozick's (1978) libertarianism, for example, fails to be reasonable in the appropriate sense because it denies certain all-purpose resources as necessarily accompanying liberties in order that people can make full use of them, and claims instead that the unfettered market is the appropriate mechanism for setting the baseline distribution of such resources. Whilst Nozick's view does not depend on any particular conception of the good - his claims about self-ownership and private property rest on a conception of what we may legitimately do (or not do) to one another, not on a conception of what makes life valuable - and is a political conception in that sense, it is not a liberal conception because it fails to meet the reciprocity criterion. Liberal conceptions, according to Rawls, are uniquely placed to meet the requirements of reciprocity because only such conceptions display a sufficient level of concern for the advantage of every individual (see Rawls 1996: lviii).

The response here, then, is not to deny the existence of disagreement about distributive justice, but to point to the fact that most actual disagreement is unreasonable, and thereby irrelevant. That is, the scope of disagreement about distributive justice is significantly narrowed once it is recognised that it is only disagreement between reasonable views that is of importance. Reasonable disagreement will occur (albeit amongst a narrower range of views) over which principle best fulfils the reciprocity requirement. To show a sufficient level of concern for the advantage of every individual such a principle must be, to some extent, egalitarian in nature. Within the Rawlsian theory the difference principle is one possible principle from a set of such principles. Moreover, Rawls believes it to be the most appropriate principle for the task of fulfilling the reciprocity requirement (Rawls 1996, p.xlix; Quong 2011, pp.204-12).

Drawing out this dilemma and response has also provided another means by which to indicate the profound consequences for education of the view I have outlined and defended. The aim of a political liberal education for citizenship - as encapsulated in Rawls's statement of encouraging 'the political virtues so that they want to honor the fair terms of social cooperation in their relations with the rest of society' (Rawls 1996, p.199) - must be to develop in citizens an 
commitment to democratic deliberation that is constrained or framed by both the virtues of civility (a recognition of the burdens of judgment) and an understanding of the significant social and economic requirements of reciprocity (Clayton 2006, p.150). This will necessarily include an understanding of the place and role of environmental goods and requirements that contribute to those social and economic resources. 'Just as children should be educated to abhor law and policy that discriminates on racial or sexual grounds, they should also be brought to appreciate the injustice of political ideologies that do not afford citizens the right kinds of concern or respect.' (Clayton 2006, p.150). Libertarian views that fails to offer health, opportunity, wealth and income, is one case in point. Views that relegate crucial environmental resources to matters of mere preference is another.

This answer to the dilemma, however, raises a second potential objection, to wit, that teaching about justice within the educational curriculum is not permitted because it undermines the standard of legitimacy upon which political liberalism replies. A version of this criticism is articulated by Brighouse (1998). Brighouse objects to the kind of model of civic education - the more expansive version - that I have been defending here; namely, one that seeks to shape the political motivations of individuals by, among other things, teaching about the content of what justice requires. Such a model goes beyond simply providing individuals with the skills to reflect rationally and critically on political matters, and to participate in the political process, should they choose to. At first it looked like Rawls's model was the latter kind; I have argued it is closer to the former, especially when environmental justice is considered.

Brighouse objects that shaping the political motivations of individuals via an education about justice undermines legitimacy because, by definition, legitimacy requires free, informed, and rational consent. Teaching about justice skews the outcome in favour of itself. It is hardly surprising that individuals 'consent' to a conception of justice they have already been indoctrinated into. This is hardly free and rational consent, the objection goes. To illustrate this, Brighouse gives two criteria by which legitimacy can be measured. The first is that political arrangements must be such that citizens would consent to them if they were reasonable, possessed of sufficient information, and capable of reasoning in a manner that was not overly self-interested. Brighouse's worry here is that this hypothetical consent is too easily attained. Thus, he adds the second criterion, that there must also be actual consent given by the governed (and that this too must be free, rational, and informed). This rules out, it seems, the interpretation of political liberal education I have expounded, because teaching about justice is 
construed as manipulative, and hence, not free. 'If we carefully foster the virtues among those who are not yet able rationally to assess the legitimacy of the state itself, what basis do we have to think they would have freely supported it on the basis of their reason alone?' (Brighouse 1998, p.723).

Is this an adequate objection? I do not believe so. Two brief reasons will indicate why not. ${ }^{6}$ First, Brighouse's claim that actual consent is the 'usual' criterion added to the standard of legitimacy (after hypothetical consent) is inaccurate if we interpret this to mean in the accounts of leading liberal theorists. Rawls, Dworkin, and Raz (to name a few) do not consider actual consent to be a requirement of legitimacy. Rawls relies upon his conception of a 'natural duty of justice' to generate consent (Rawls 1971, pp.114-117). Dworkin adopts a form of 'associative duties' to ground consent (1986). And Raz utilizes a mechanism to generate an obligation to obey the law where complying with a given law enables an individual to better act on her reason for actions than not complying with it (1988). Second, on a proper and plausible account of legitimacy it is not correct that hypothetical consent is too easily attained. An account that rests on stringent ideals of justice and democracy will place significant demands on political principles and institutions, not ones that are weak and easily met (see Clayton 2006, p.134).

If this broad reply to the charge that justice-based concerns cannot be taught as part of a compulsory education for fear of undermining legitimacy is correct, then not only can important aspects of environmentalism be taught, but they must be. They must be, because they form a basic requirement of learning about the fair terms of social cooperation.

Finally, I want to turn to consider in slightly more detail, exactly what can be taught under the rubric of environmental justice consistent with a political liberal educational curriculum, and what gets left out. It is inevitable that some things will get left out. Not everything that is of concern to environmentalism will be subsumable within the category of primary social goods; not every environmentalist concern with be a concern of justice. Some things will remain beyond justice; that is, matters that are more appropriately conceived of as part of a broader conception of the good. This is not necessarily regrettable. To say something is not a consideration of justice is not to say that it does not matter. It may well matter on other grounds, and it may well matter more. Indeed, it has been my purpose to argue that other attempts to reconcile environmental conceptions of justice and liberal - particularly political liberal - conceptions of political morality

\footnotetext{
${ }^{6}$ Here I follow the excellent discussion of this matter in Clayton 2006, pp.133-145.
} 
include too little of the former, such that they are unappealing to environmentalists. The reconciliation I have defended here has sought to include a wider array - the proper array - of environmental goods, though not everything.

Those aspects of environmentalism that are not properly part of the requirements of justice will be subject to decision-making via the democratic process. Citizens, that is, can attempt to convince their fellow citizens of the importance of their non-political values, and to assign public funds in that regard, via deliberation, debate, and voting. As Bell writes: 'Liberal citizens are entitled to vote their ecocentric ideals and a liberal state may promote ecocentric policies that have been endorsed through the democratic process.' (Bell 2006, p.215). Similarly, citizens might decide that schools would - either collectively or individually - be better teaching more about the environment and its worth, preservation, and care than what justice requires because, as a society they are convinced of its worth, just as some do with regard to such things as religious faiths.

Identifying what should be included, however, is a tricky business. What is clear from our understanding of the environment and the scientific processes behind it, is that we still understand relatively little about its myriad causal mechanisms and their interrelatedness. The provision of a decent environment as a precondition to the effective realisation of other primary goods will cover many concerns, but it will also leave some outside. This is because the composition of what constitutes a decent or sufficient environment will be complex and may take many varied forms. Under one schema a particular species might be essential, under another it might not be. It is only a requirement of justice that such a decent environment be provided so as to facilitate the realisation of the other parts of the view. The specifics of how such a schema is to be fleshed out is not something that is set out directly by a conception of justice. Given the complexity of the environment, we may need to assume that many apparently unconnected aspects of the ecosystem play an integral part in maintaining a decent environment.

A simple analogy helps. A basic duty of parenting is the duty to provide one's child with a nutritious diet. I shall assume, for the sake of argument, that vegetarianism is not morally required. So long as the diet meets the basic criteria for being considered nutritious it does not matter what the component parts are. Thus, there is no particular reason to provide one's child with chicken so long as the necessary nutrients that would be obtained from chicken (primarily protein) are obtained from other food sources (soya, milk, red meat, eggs, beans, and so forth). 
How we flesh out the set of goods that comprises a nutritious diet is up to us as parents.

However, given the various food groups and nutrients that are essential to a healthy diet, and the limited numbers of foods available, any adequate schema is likely to overlap significantly with any other. Similarly, how we flesh out the package of environmental goods that we need to lead decent lives is likely to vary, but whichever is endorsed it is likely to overlap significantly with any alternative.

\section{Conclusion}

My aim has been straightforward: to argue that a strong environmentalist ethic and the educational curriculum it is often thought to demand is, in large part, compatible with the very stringent requirements of a political liberal framework and the constraints it places upon civic education. I have aimed to achieve this reconciliation by arguing that environmental goods - and the values that surround them - are more accurately and appropriately conceived of as primary social goods, not belief systems. As such, they fall under the heading of socioeconomic justice, not conceptions of the good. Proponents of political liberalism need only endorse an antiperfectionist stance with regard to conceptions of the good. About questions of justice they can endorse a partisan view that promotes distributive schemes of environmental goods, and which can legitimately be taught in the classroom as part of a national curriculum with the aim of creating greener citizens.

\section{References}

Barry, B. 1995. Justice as Impartiality, Oxford: Clarendon Press.

Baxter, B. 2000. Ecological Justice and Justice as Impartiality. Environmental Politics, 9 (3), 43-64.

Baxter, B. 2005. A Theory of Ecological Justice. London: Routledge.

Baxter, B., 2006. 'Political Liberalism, the non-human biotic and the abiotic', Analyse \& Kritik, 28, 190-205. 
Bell, D. 2002. How Can Political Liberals Be Environmentalists?', Political Studies, 50 (2) $703-24$

Bell, D. 2004a. 'Creating Green Citizens? Political Liberalism and Environmental Education'. Journal of Philosophy of Education. 38 (1), 37-53.

Bell, D. 2004b. Environmental Justice and Rawls' Difference Principle. Environmental Ethics, 26 (4), 287-306.

Caney, S. 1999. 'Liberal Legitimacy, Reasonable Disagreement and Justice'. In: R. Bellamy and M. Hollis, eds. Pluralism and Liberal Neutrality, London: Routledge.

Clayton, M. 1999. 'Political Liberalism, Disagreement, and Sectarianism', Polis 1 (3), 71-92.

Clayton, M. 2006. Justice and Legitimacy in Upbringing. Oxford: Oxford University Press.

Dobson, A. 1998. Justice and the Environment: Conceptions of Environmental Sustainability and Theories of Distributive Justice, Oxford: Oxford University Press.

Dworkin, R. 1986. Law's Empire. Cambridge, MA.: Harvard University Press.

Low, N., and B.Gleeson. 1998. Justice, Society, and Nature: An Exploration of Political Ecology, London: Routledge.

Nozick, R. 1978. Anarchy, State, and Utopia, Oxford: Blackwell.

Nussbaum, M., 2006. Frontiers of Justice: Disability, Nationality, Species Membership, London: The Belknap Press.

Rawls, J. 1971. A Theory of Justice, Oxford: Oxford University Press.

Rawls, J. 1993. Political Liberalism, New York: Columbia University Press. 
Rawls, J. 1996. 'Introduction to the Paperback Edition', Political Liberalism, New York: Columbia University Press.

Rawls, J. 2001. Justice as Fairness: A Restatement, Cambridge, MA.: Harvard University Press.

Raz, J. 1988. The Morality of Freedom. Oxford: Clarendon Press.

Stephens, C., Bullock, S. and A.Scott, 2001. Environmental Justice: Rights and Means to a Healthy Environment for All, ESRC Briefing Paper No. 7. London: Economic and Social Research Council.

Wissenberg, M. 1998. Green Liberalism: The Free and Green Society, London: UCL Press. 